prevention of viral diseases of animals. Development and production in Belarus]. Minsk: Belarusian Science [in Russian].

23. Mishaeva, N.P., Tsvirko, L.S., \& Pavlichenko, S.P. (2004). Beshenstvo v Belarusi. Problemy zashchity naseleniya [Rabies in Belarus. Problems of Population Protection]. Minsk: Belarusian Science [in Russian].

\title{
УДК 61:575.1.577.21[543.054:543.635.28]
}

МУЗИКА В.П., д-р вет. наук, ст. наук. сп., е-mail: viktormuzyka@ gmail.com, ЛЕВИЦЬКИЙ Т.Р., канд. с.-г. наук, e-mail: taraslev@i.ua, НАЗАР Б.І., канд. вет. наук, e-mail: bobnaz@ukr.net Державний науково-дослідний контрольний інститут ветеринарних препаратів та кормових добавок

МАНДИГРА Ю.М., канд. вет. наук, е-mail: mandyhra.iawp@gmail.com Дослідна станиія епізоотології IВМ НАAН

\section{ВИКОРИСТАННЯ МОЛЕКУЛЯРНО-БІОЛОГІЧНИХ МЕТОДІВ ДОСЛІДЖЕНЬ ДЛЯ НЕДОПУЩЕННЯ ВИНИКНЕННЯ ПРІОННИХ ІНФЕКЦІЙ В УКРАЇНІ}

У статті представлена інформація про використання молекулярних методів досліджень для визначення видової належності білків тваринного походження, а саме великої рогатої худоби для того, щэоб не допустити фальсифікацію продукиії $i$, як наслідок, попередити поширення пріонних інфекцій.

Впровадження скринінгових $i$ підтверджувальних методів виявлення фальсифікованих продуктів харчування, кормів $і$ кормової сировини дозволить ефрективно $i$ оперативно виявляти випадки фальсифікаиії, попереджати попадання в обіг неякісних продуктів і кормів, запобігти захворюванням тварин пріонними інфекціями $i$, як наслідок, отримувати безпечну $і$ якісну продукцію тваринництва.

Ключові слова: молекулярні методи досліджень, метод ПЛР, видова диференціащія білків тваринного походження, пріонні інфекиії.

Вступ. Безпека та якість харчових продуктів для людей і кормів для тварин має бути пріоритетним напрямком діяльності спеціалістів ветеринарної медицини, що базується на впровадженій комісією Codex Alimentarius, спільно iз Всесвітньою організацією охорони здоров'я (WHO) програмі харчових стандартів, метою якої $\epsilon$ захист здоров'я споживачів i недопущення фальсифікації продукції. Нешкідливі та безпечні харчові продукти можуть бути отримані виключно від здорових тварин, які утримувались у відповідних санітарно-гігієнічних умовах при мінімальному стресі [1].

Пріонні хвороби виявлені або штучно відтворені у багатьох домашніх і диких тварин: свиней, котів, шимпанзе, мавп, хом'яків, мишей, норок, лосів, антилоп, гепардів, пум, тигрів, ньяли, куду, ориксів, страусів. Хвороби можуть передаватися від однієї тварини до іншої, від одного виду до другого. Однак головна небезпека всіх пріонних захворювань у тому, що від тварин можуть заражатися і люди. Відомо 10 нозологічних форм пріонної етіології, з них 4 - 
хвороб людини: хвороба Крейтцфельда-Якоба (ХКЯ), куру, синдром Гертманна-Штреусслера- Шейнкера (СГШШ) і фатальна сімейна інсомія (ФСI) $[2,3]$.

Трансмісивні губкоподібні енцефалопатії (ТГЕ) (англ. Transmissible spongiform encephalopathies (TSE) - хронологічно перше визначення, яке об'єднує групу з 4 повільних інфекцій за наявністю губкоподібних змін у нервовій тканині як загальної ознаки (скрепі, ТЕН, куру та ХКЯ), дане К. Gajdusek та ін. У 1969 р. Це визначення є сенсовим аналогом терміну «пріонні інфекції», який був запропонований пізніше S. Prusiner (1982) [4, 5].

Дослідники пов'язують виникнення пріонних захворювань у Великобританії і інших країнах Європи із застосуванням м'ясо-кісткового борошна, одержаного під час переробки хворих тварин, уражених скрепі чи іншими (хворобами) пріонними інфекціями. Розвиток пріонних інфекцій полягає в тому, що пріонний білок, який потрапляє у організм людини із зараженим м'ясом, запускає процес перетворення нормального білка у аномальний.

На жаль, дотепер у всіх країнах світу достовірною вважається лише посмертна діагностика пріонних енцефалопатій [6].

Мета роботи. Метою роботи $є$ запобігання виникнення пріонних інфекцій, а саме ідентифікації видової належності білків тваринного походження гістологічними та ПЛР методами контролю продукції, які дають можливість диференціювати складові компоненти їі, оскільки всі м'ясні продукти, та сировина для кормів тваринного походження проходячи стадію технологічної обробки, і в готовому вигляді, переважно, не зберігають свої морфологічні особливості.

Матеріали і методи досліджень. Дослідження проводились методом мікроскопічного аналізу з підтвердженням позитивних результатів методом полімеразної ланцюгової реакції.

Результати досліджень та їх обговорення. У рамках державного моніторингу протягом 2012-2017 pp. Державним науково-дослідним контрольним інститутом ветеринарних препаратів та кормових добавок проводиться контроль якості кормів для непродуктивних тварин, преміксів, кормових добавок, вітамінів включаючи в себе визначення наявності в них білків жуйних тварин. Адже білки жуйних тварин можуть бути інфіковані пріоновою інфекцією. Тому постало питання не допустити у раціон тварин білків жуйних тварин, особливо коли ці корми поступають із країн, де поширена пріонова інфекція і є заборона щодо ввозу м'яса, що дає змогу не допустити розповсюдженню інфекції.

Було проведено випробовування 830 зразків кормових матеріалів, 405 зразків комбікорму для жуйних тварин і 1100 зразків комбікорму для інших тварин. У 34 (3,52\%) зразках вихідних матеріалів було виявлено наявність обробленого тваринного білка $з$ наземних тварин, і 26 (2,69\%) зразків показали наявність обробленого тваринного білка, отриманий з риби.

Комбікорми для жуйних тварин були більш забрудненими компонентами 
тваринного походження, $74(5,88 \%)$ зразки - наявність обробленого тваринного протеїну 3 наземних тварин, і $126(10,02 \%)$ - наявність обробленого тваринного протеїну риби.

Отримані результати вказують на високий відсоток внесення кормів тваринного походження. Найбільший відсоток зразків $(15,9 \%)$, в яких було виявлено наявність білків, що переробляються, були кормовими сумішами для не жуйних тварин. Із 1100 зразків комбікорму для не жуйних тварин 98 (8,27\%), це були зразки, відібрані на фермах.

У період з 2012 по 2017 рік включно нами було проведено 629 визначень методом ПЛР по виявленню наявності білків жуйних тварин у кормах для непродуктивних тварин, преміксах і білково-вітамінних добавках та іншому (фарші різного походження, супах, ветеринарних препаратах) котрі завозяться в Україну по імпорту.

При проведенні досліджень було виявлено наявність білків жуйних тварин у 64 пробах із 402 кормів для непродуктивних тварин, котрі поступили для реєстрації даної продукції в Україні. Крім цього, їх було виявлено в 12 пробах іншої продукції (фарші різного походження, супах, ветеринарних препаратах) при спробі завезення в Україну. Отримані результати наведено в таблиці 1.

Таблиия 1

Результати по ПЛР за 2012-2017 роки

\begin{tabular}{|c|l|c|c|c|}
\hline № & \multicolumn{1}{|c|}{ Досліджувані зразки } & Всього & Негативні & Позитивні \\
\hline 1. & Загальна кількість визначень & 629 & 558 & 71 \\
\hline 2. & Корми для непродуктивних тварин & 402 & 338 & 64 \\
\hline 3. & Премікси, білково-вітамінні добавки & 116 & 166 & - \\
\hline 4. & $\begin{array}{l}\text { Комбікорми, корми для с.-г. тварин, птиці } \\
\text { та риб, борошно рибне і тваринного } \\
\text { походження }\end{array}$ & 29 & 29 & - \\
\hline 5. & $\begin{array}{l}\text { Інше (фарші різного походження, супи, } \\
\text { препарати та інше) }\end{array}$ & 67 & 55 & 12 \\
\hline
\end{tabular}

Для запобігання розповсюдження пріонних інфекцій в Україні у реєстрації з подальшим завезенням до України продукції, в якій виявлено білки жуйних тварин, було відмовлено.

Метод визначення видової приналежності м'яса і м'ясних інгредієнтів, що входять до складу продовольчої сировини тваринного походження, кормів і готових харчових продуктів необхідний для підтвердження якості й автентичності цих зразків. Найчастіше при лабораторному дослідженні деяких проб, у їхньому складі можуть бути знайдені компоненти, не задекларовані виробником, або навпаки, відсутні заявлені інгредієнти, тобто, встановлювалась фальсифікація цих продуктів (табл. 2). Межа виявлення залежала від глибини переробки досліджуваної проби (у тому числі, від глибини термообробки) і від складу зразка. Наприклад, межа виявлення різних видів м'яса в сосисках чи в іншій готовій м'ясній продукції складала приблизно $1 \%$ і більше. При 
дослідженні кормів межа виявлення звичайно складала 0,5\% i більше, у залежності від складу зразка.

Таблиця 2

Результати встановлення видової належності тканин тварин ПЛР методом (2012-2017 pp.)

\begin{tabular}{|l|l|c|c|c|c|}
\hline \multirow{2}{*}{ № } & \multicolumn{1}{|c|}{ Досліджувані зразки } & \multirow{2}{*}{ Всього } & \multicolumn{3}{|c|}{ Виявлено незадекларованих тканин } \\
\cline { 4 - 6 } & & BPX & Птиці & Свиней \\
\hline 1. & Корми для непродуктивних & 80 & 8 & 10 & 7 \\
\hline тварин & Фарші різного походження & 60 & 12 & 7 & - \\
\hline 3. & Супи, препарати та інше & 10 & 2 & 1 & - \\
\hline 4. & Інше & 15 & 2 & 6 & 3 \\
\hline
\end{tabular}

Висновки та перспективи подальших досліджень. Застосування комплексного підходу до виявлення компонентів тваринного походження у кормах та продуктах харчування $\epsilon$ ефективним механізмом попередження пріонних захворювань. Використання методу ПЛР для підтвердження наявності та визначення видової належності тканин тварин дозволяє запобігати фальсифікації продукції, проводити диференціацію видової належності протеїнів у складі кормів для тварин i м’ясних продуктах, що становить важливе економічне й епідеміологічне значення, а в подальшому попередить виникнення пріонних інфекцій, які небезпечні як для людей, так і для тварин.

\section{СПИСОК ЛІТЕРАТУРИ}

1. ПЛР-діагностики в системі запобігання поширенню губчастої енцефалопатії / М.В. Косенко, В.О. Величко, Т.Р. Левицький та ін. // Аграрні вісті. - 2004. - № 3. - С. 10-11

2. Волос Л.І. Пріонові інфекції // Основи патологічної анатомії людини. - К., 1999. C. 399-406.

3. Прионы и инфекции, вызываемые ими у человека и животных / Киселев О.И., Некрасов П.А., Решетникова О.Ю., Воробьев А.А. // Эпидемиология и инфекционные болезни. - 1998. - № 1. - С.4-9.

4. Шлопов В.Г. Пріонові інфекції: підсумки та перспектива дослідження / В.Г. Шлопов, Л.І. Волос // Інфекційні хвороби. - 1999. - № 2. - С. 5-9.

5. Вербицький П.І. Губчастоподібна енцефалопатія великої рогатої худоби / П.І. Вербицький // Ветеринарна медицина України. - 2003. - № 4. - С. 10-11.

6. Коцюмбас I.Я. Методи лабораторного контролю та ідентифікації тканин тваринного походження у кормах / І.Я. Коцюмбас, Т.Р. Левицький // Ефективні корми та годівля. - 2008. - № 8 (32). - С. 13-15.

ИСПОЛЬЗОВАНИЕ МОЛЕКУЛЯРНО-БИОЛОГИЧЕСКИХ МЕТОДОВ ИССЛЕДОВАНИЙ ДЛЯ НЕДОПУЩЕНИЯ ВОЗНИКНОВЕНИЯ ПРИОННЫХ ИНФЕКЦИЙ В УКРАИНЕ / Музика В.П., Левицкий Т.Р., Назар Б.И., Мандыгра Ю.Н.

Применение комплексного подхода $к$ выявлению компонентов животного происхождения в кормах и продуктах питания является эффективным механизмом предупреждения прионных заболеваний. Использование метода ПЦР для подтверждения наличия $u$ определения видовой принадлежности тканей жсивотных позволяет предотвращуать фальсификациии продукции, проводить дифференциачиюю видовой принадлежности протеинов в составе кормов для животных и мясных продуктах, 
составляет важное экономическое и эпидемиологическое значение, $а$ в дальнейшем предотвратит возникновение прионных инфекиий опасные как для людей, так и для животных в Украине.

Ключевые слова: молекулярные методы исследований, метод ПЦР, видовая дифференциачия белков животного происхождения, прионные инфекции.

\section{USE OF MOLECULAR-BIOLOGICAL METHODS OF RESEARCHES FOR NON- ADMISSION OF ORIGIN PRION INFECTIONS IN UKRAINE / Muzyka V.P., Levytsky T.R., Nazar B.I., Mandyhra U.M.}

Introduction. Use of the gene technology to analyze the quality of food products for humans and animal feed is required. For this purpose sensitive, fast and accurate method could be used to detect and prevent falsifications, in particular, falsified food products, animal feeds and food additives, the actual composition of which does not correspond to the declared and to the labeling information.

Application of the screening and confirmatory methods for detecting falsified food products, animal feeds and feed materials will provide efficient and prompt detection falsification cases, to prevent circulation of low-quality food products and feeds, decreasing the productivity and poisoning of animals, and consequently to obtain safe and high-quality livestock products.

The goal of the work was to the prevent cases prion infections, namely identification of animal proteins using histological and PCR methods that allow differentiate the constituents of food, because meat products, and the raw material for feed of animal origin at the stage of technological processing mainly, do not retain their morphological features.

Materials and methods. The researches were carried out using microscopic analysis with the help of confirmation of positive results by polymerase chain reaction method.

Results of research and discussion. Within the framework of state monitoring during 20122017, the State Scientific- Research Control Institute of Veterinary Medicinal Products and Feed Additives conducted the quality control of feed for non-productive animals, premixes, feed additives, vitamins, including the determination of the presence of proteins of ruminants. The presence of proteins of ruminants was found in 64 out of 402 samples of feed supplements for nonproductive animals, which were submitted for the registration in Ukraine. Besides this, these proteins was found in 12 samples of other products (minced meat of various origin, soup, veterinary preparations) when trying to import to Ukraine. To prevent the spread of prion infections in Ukraine, the registration of these products with the further shipment to Ukraine, was denied.

Conclusions and prospects for further research. The application of an integrated approach to the recognizing of animal components in feed and food is an effective mechanism for preventing prion diseases. The use of the PCR method for confirmation of the presence and identification of species of animal tissues allows to prevent the falsification of products, to differentiate the species belonging of proteins in the composition of feed for animals and meat products, that presents an important economic and epidemiology value, and in future will warn the emergence of prion infections which are dangerous as for people so for animals.

Keywords: molecular research methods, PCR method, species identification of the protein of animal and vegetable sources.

\section{REFERENCES}

1. Kosenko, M.V., Velychko, V.O., Levitsky, T.R., Nazar, B.I., Kushnir, G.V., \& Shariy, T.I. (2004). PCR-diagnostics in the system of prevention of spongiform encephalopathy [PCR diagnostics in the system of prevention of the spread of spongiform encephalopathy]. Agrarni visti-Agrarian news, 3, 10-11 [in Ukrainian].

2. Volos, L.I. (1999). Osnovy patologichnoji anatomiji ljudyny [Fundamentals of human pathological anatomy]. Kyiv [in Ukrainian].

3. Kiseljov, O.I. Nekrasov, P.A., Reshetnikova, O.Yu, \& Vorobjov, A.A. (1998). Priony i infekcii, vyzyvaemye imi u cheloveka i zhivotnyh [Prions and infections caused by them in humans 
and animals] Epidemiologija i infektsionnye bolezni - Epidemiology and infectious diseases, 1, 4-9 [in Russian].

4. Shlopov, V.G., \& Volos, L.I. (1999). Prionovi infektsii: pidsumky ta perspectiva doslidzhennja [Prion infections: the results and perspectives of research]. Infekcijni hvoroby Infectious diseases, 2, 5-9 [in Ukrainian].

5. Verbytskij, P.I. (2003). Hubchastopodibna entsefalopatia velykoi pogatoi khudoby [Spongiform encephalopathy of cattle]. Veterynarna medycyna Ukrai'ny - Veterinary Medicine of Ukraine, 4, 10-11 [in Ukrainian].

6. Kotsyumbas, I.Ya., \& Levitsky, T.R. (2008). Metody laboratornogo kontrolju ta identyfikacii' tkanyn tvarynnogo pohodzhennja u kormah [Methods of laboratory control and identification of tissues of animal origin in feeds]. Efektyvni kormy ta godivlja - Effective feed and nutrition, 8(32), 13-15 [in Ukrainian].

\section{УДК 636.5.09:639.12:616.9-047.36(477)}

ПІЩАНСЬКИЙ О.В., e-mail: dndildvse@vetlabresearch.gov.ua,

САПАЧОВА М.А., канд. вет. наук, e-mail: m_sapacheva@meta.ua,

СУШКО М. I., e-mail: m.i.sushko@gmail.com,

УСАЧЕНКО Н.В., e-mail: nataliia.usachenko@gmail.com,

МЕЖЕНСЬКИЙ А.О., канд. вет. наук, е-mail: mezhaavet@gmail.com,

КИївСЬКА Г.В., канд. вет. наук, e-mail: vcheny.secretar@gmail.com

Державний науково-дослідний інститут з лабораторної діагностики та ветеринарно-санітарної експертизи

\section{МОЛЕКУЛЯРНО-ГЕНЕТИЧНИЙ МОНІТОРИНГ ГРИПУ СЕРЕД ДИКОЇ ТА ДОМАШНЬОЇ ПТИЦІ В УКРАЇНІ ЗА 2016-2017 РОКИ}

Наведено результати моніторингових досліджень щодо пташиного грипу серед дикої та домашньої птищі за 2016-2017 рр. Виявлення РНК, субтипування вірусу по гемаглютиніну H5, H7 $i$ визначення нейроамінідази проводили методом полімеразної ланцюггової реакції. Проведено аналіз результатів повногеномного секвенування вірусів, виявлених на території України.

Підтверджено, щуо вірус, який циркулював на території України в 2016-2017 рр. відноситься до субтипу H5N8, є високопатогенним, і є ідентичними з вірусами грипу птичі субтипу H5N8, які цииркулюють в теперішній час на території Свропи та Азії.

Ключові слова: грип птиці, діагностика, епізоотична ситуація, моніторинг.

Вступ. Згідно класифікації Міжнародного епізоотичного бюро(МЕБ) вірус пташиного грипу відноситься до категорії особливо небезпечних хвороб птиці $[1,2]$. МЕБ відмічає, що з 2013 року спостерігається друга хвиля грипу птиці. Ситуація ускладнюється циркуляцією різноманітних підтипів вірусу, що створює значні труднощі в організації контролю і ліквідації спалахів. Порівнюючи 3 першою хвилею (з 2005 по 2012 роки) у теперішній час відмічається зростання числа циркулюючих підтипів вірусу грипу птиці з 4 до 12 [4]. 